\title{
Metformin in skin diseases
}

\section{Metformina w chorobach skóry}

Damian Kadylak', Karina Polak', Kamila Wojciechowska', Beata Bergler-Czop²

'The Dermatology Ward of the Independent Public "A. Mielęcki" Teaching Hospital, Katowice, Poland

2Department of Dermatology, Silesian Medical University, Katowice, Poland

'Oddział Dermatologii, Samodzielny Publiczny Szpital Kliniczny im. A. Mielęckiego, Katowice, Polska

${ }^{2}$ Katedra i Klinika Dermatologii, Śląski Uniwersytet Medyczny, Katowice, Polska

Dermatol Rev/Przegl Dermatol 2021, 108, 27-37

DOI: https://doi.org//0.5 I 4/dr.2021.10589|

\section{CORRESPONDING AUTHOR/ ADRES DO KORESPONDENCJI:} dr hab. n. med. Beata Bergler-Czop Katedra i Klinika Dermatologii Śląski Uniwersytet Medyczny ul. Francuska 20/24 40-027 Katowice tel.: +48501352033 e-mail: bettina2@tlen.pl

\begin{abstract}
Metformin is the most widely used oral antidiabetic drug in the world. It is the first-line drug in type 2 diabetes, where its inhibiting effect on hepatic glucose production, increasing muscle and adipose tissue insulin sensitivity and reduction of glucose absorption in the gut are used. Many benefits to the skin condition have been reported from using metformin in dermatological diseases such as acne vulgaris, hidradenitis suppurativa, hirsutism as well as reducing the risk of certain skin malignancies and the occurrence of psoriasis. Some adverse effects of metformin have also been reported: rash, skin allergic reactions, drug reaction with eosinophilia and systemic symptoms (DRESS syndrome), bullous pemphigoid, leukocytoclastic vasculitis, nail discoloration with subungual hyperkeratosis. The article is a review of currently available literature on the influence of metformin on the course of various skin diseases and its adverse effects.
\end{abstract}

\section{STRESZCZENIE}

Metformina jest najczęściej stosowanym na świecie doustnym lekiem przeciwcukrzycowym. Stanowi lek pierwszego wyboru w terapii cukrzycy typu 2, gdzie wykorzystywany jest jej efekt hamowania wątrobowej produkcji glukozy, zwiększania insulinowrażliwości mięśni i tkanki tłuszczowej oraz zmniejszania wchłaniania glukozy w jelitach. W piśmiennictwie istnieje wiele doniesień o korzystnym wpływie metforminy na stan skóry w chorobach dermatologicznych, takich jak trądzik zwyczajny, hidradenitis suppurativa, hirsutyzm, a także o redukowaniu ryzyka rozwoju niektórych nowotworów złośliwych skóry oraz wystąpienia łuszczycy. Donoszono także o niepożądanych działaniach metforminy: występowaniu osutek, skórnych reakcji alergicznych, reakcji polekowej z towarzyszącą eozynofilią i objawami ogólnymi (drug rash with eosinophilia and systemic syndrome - DRESS), pemfigoidu pęcherzowego, leukocytoklastycznego zapalenia naczyń, przebarwień paznokci z podpaznokciową hiperkeratozą. Artykuł stanowi przegląd dostępnej literatury dotyczącej wpływu metforminy na przebieg różnych chorób skóry oraz jej działań niepożądanych.

Key words: metformin, skin diseases, diabetes.

Słowa kluczowe: metformina, choroby skóry, cukrzyca. 


\section{INTRODUCTION}

Metformin is a drug known since the 1920s. In 1957, French physician Jean Sterne used it for the first time to treat diabetes [1]. In 1998, the UK Prospective Diabetes Study (UKPDS) showed a beneficial effect of metformin in reducing the risk of cardiovascular disease [2]. Currently, metformin is the most widely used oral anti-diabetes drug in the world [1]. The mechanism of action of the drug is multidirectional. The use of metformin inhibits hepatic glucose production, increases sensitivity of peripheral tissues (muscles, adipose tissue) to insulin, reduces production of free fatty acids in adipose tissue and reduces absorption of glucose in the intestines. At the cellular level, these effects are primarily caused by activation of the AMP protein kinase (adenosine monophosphate kinase - AMPK) [3]. In the literature, there are also many reports on the possible use of metformin in dermatology. In this article, we are reviewing the available literature on the effects of metformin on the course of various skin diseases and adverse effects of the drug in this respect.

\section{ACNE VULGARIS}

Acne vulgaris, one of the most common skin diseases, occurs mainly in adolescents, but can appear in almost any age group. This disease affects both mental and physical spheres of patients. According to the guidelines of the World Health Organization, acne vulgaris can be considered a social disease.

Acne vulgaris is a complex disease with a multifactorial etiopathogenesis, in which the following are important: overproduction of sebum by sebaceous glands, excessive keratosis of sebaceous glands and their outlets, development of bacterial flora (colonization by Cutibacterium acnes) and release of inflammatory mediators in the skin [4]. In some chronic diseases, there is a noticeable relationship between acne vulgaris and disorders of insulin metabolism. Polycystic ovary syndrome (PCOS) is one of them, in which obesity, hyperinsulinemia, insulin resistance and hyperandrogenism are observed. These changes are often accompanied by acne vulgaris. High levels of insulin-like growth factor-1 (IGF-1) and hyperinsulinemia in PCOS patients induce androgen production, while inhibiting hepatic synthesis of sex hormone binding globulin (SHBG), which increases bioavailability of androgens. Androgens play an important role in increasing the size of sebaceous glands, stimulating sebum production, and stimulating proliferation of keratinocytes in the sebaceous unit. Hyperinsulinemia increases serum IGF-1 levels and reduces insulin-like growth factor binding protein 3 (IGFBP3) levels. These two factors directly

\section{WPROWADZENIE}

Metformina jest lekiem znanym od lat 20. XX wieku. W 1957 roku francuski lekarz Jean Sterne po raz pierwszy wykorzystał ją do leczenia cukrzycy [1]. W 1998 roku w badaniu UK Prospective Diabetes Stu$d y$ (UKPDS) stwierdzono korzystny wpływ metforminy na zmniejszenie ryzyka wystąpienia chorób krążenia [2]. Obecnie metformina jest najczęściej stosowanym na świecie doustnym lekiem przeciwcukrzycowym [1]. Mechanizm jej działania jest wielokierunkowy. Zastosowanie metforminy powoduje zahamowanie wątrobowej produkcji glukozy, zwiększenie insulinowrażliwości tkanek obwodowych (mięśnie, tkanka tłuszczowa), zmniejszenie produkcji wolnych kwasów tłuszczowych w tkance tłuszczowej oraz zmniejszenie wchłaniania glukozy w jelitach. Na poziomie komórkowym za te efekty odpowiada przede wszystkim aktywacja kinazy białkowej AMP (adenosine monophosphate kinase - AMPK) [3]. W piśmiennictwie istnieje ponadto wiele doniesień na temat możliwości zastosowania metforminy $\mathrm{w}$ dermatologii. W artykule dokonano przeglądu dostępnego piśmiennictwa dotyczącego wpływu metforminy na przebieg różnych chorób skóry oraz jej działań niepożądanych.

\section{TRADZIK POSPOLITY}

Trądzik pospolity, jedna z najczęstszych chorób skóry, występuje głównie u młodzieży, ale może pojawiać się w prawie każdej grupie wiekowej. Choroba ta wpływa zarówno na sferę psychiczną, jak i fizyczną pacjentów. Zgodnie z wytycznymi Światowej Organizacji Zdrowia trądzik pospolity może być uznawany za chorobę społeczną.

Trądzik pospolity jest złożoną chorobą o wieloczynnikowej etiopatogenezie, w której znaczenie mają: nadprodukcja łoju przez gruczoły łojowe, nadmierne rogowacenie przewodów wyprowadzających i ujść gruczołów łojowych, rozwój flory bakteryjnej (kolonizacja Cutibacterium acnes) i uwalnianie zapalnych mediatorów w skórze [4]. W niektórych chorobach przewlekłych zauważalny jest związek między trądzikiem pospolitym a zaburzeniami metabolizmu insuliny. Taką chorobą jest zespół policystycznych jajników (polycystic ovary syndrome - PCOS), w którym obserwuje się otyłość, hiperinsulinemię, insulinooporność oraz hiperandrogenizm. Zmianom tym często towarzyszy trądzik pospolity. Wysokie stężenie insulinopodobnego czynnika wzrostu 1 (insulin-like growth factor-1 - IGF-1) i hiperinsulinemia u chorych z PCOS indukują wytwarzanie androgenów, jednocześnie hamując wątrobową syntezę globuliny wiążącej hormony płciowe (sex hormone binding globulin - SHBG), co zwiększa biodostępność androgenów. Androgeny odgrywają ważną rolę $\mathrm{w}$ zwiększaniu wielkości gruczołów łojowych, stymulowaniu produkcji łoju 
affect keratinocyte proliferation and apoptosis. IGF-1 may stimulate some comedogenic factors, such as androgens, growth hormone and glucocorticosteroids. Moreover, it increases lipid peroxidation in sebocytes, which results in increased sebum secretion [5-7].

In several studies, an increased level of IGF-1 concentration was also observed in the group of acne vulgaris non-PCOS patients compared to the control group, which confirms participation of IGF-1 in the pathogenesis of acne $[6,8,9]$.

Sharma et al. conducted a study on a group of 40 women diagnosed with acne vulgaris and PCOS. All patients received metformin at the dose of $500 \mathrm{mg}$ three times daily, for 8 weeks. As a result of the treatment, a reduction in the severity of acne was observed. Moreover, levels of testosterone, dehydroepiandrosterone and symptoms of hirsutism were reduced [10]. Many other studies also proved the effectiveness of metformin in the treatment of acne vulgaris, both in monotherapy [11-14] and in combined therapy, e.g. with topical benzoyl peroxide and oral tetracycline [15], systemic limecycline and topical adapalene in combination with benzoyl peroxide [16], pioglitazone and oral flutamide [17]. Other aspects of metformin activity were also observed: a beneficial effect on biochemical parameters (such as hyperinsulinemia, hypercholesterolemia and hyperglyceridemia), regulation of the menstrual cycle, reduction of insulin resistance, reduction of testosterone, androstenedione and free testosterone levels, and normalization of body mass index [11-13, 17].

Taking into account the above data, metformin as a drug that reduces IGF-1 levels, hyperinsulinemia and insulin resistance may be useful in the treatment of acne vulgaris [5].

\section{HIDRADENITIS SUPPURATIVA}

Hidradenitis suppurativa (HS) is a chronic inflammation affecting skin regions with apocrine glands, mainly armpits, groin and anogenital areas. Inflammatory lesions are deeply embedded and painful, developing as nodules or abscesses, prone to malacia and fistula formation. About $1 \%$ of the population is affected, most often after puberty.

Etiopathogenesis of HS has not been fully understood, but it was shown to be associated with diabetes, hypertension, hyperlipidemia, metabolic syndrome, insulin resistance and obesity [18].

It has been known for years that metformin played an important role in delaying or preventing the onset of diabetes and metabolic syndrome, and a positive effect of metformin in the treatment and control of HS symptoms was also observed $[19,20]$.

In the study group of 25 people with HS treated with metformin for 24 weeks, a significant reduction i proliferacji keratynocytów w jednostce włosowo-łojowej. Hiperinsulinemia zwiększa stężenie IGF-1 w surowicy i zmniejsza białka 3 wiążącego insulinopodobny czynnik wzrostu (insulin-like growth factor binding protein 3 - IGFBP3). Te dwa czynniki bezpośrednio wpływają na proliferację i apoptozę keratynocytów. IGF-1 może stymulować niektóre czynniki komedogenne, takie jak androgeny, hormon wzrostu i glikokortykosteroidy, ponadto zwiększa peroksydację lipidów w sebocytach, co skutkuje większym wydzielaniem łoju [5-7].

Ponadto w kilku badaniach zaobserwowano zwiększone stężenie IGF-1 u pacjentów z trądzikiem pospolitym bez zdiagnozowanego PCOS w porównaniu z grupą kontrolną, co potwierdza udział IGF-1 $\mathrm{w}$ patogenezie trądziku pospolitego $[6,8,9]$.

Sharma i wsp. przeprowadzili badanie u 40 kobiet z rozpoznanym trądzikiem pospolitym i PCOS. Wszystkim pacjentkom podawano metforminę $\mathrm{w}$ dawce $500 \mathrm{mg}$ trzy 3 dziennie przez 8 tygodni. W wyniku leczenia zmniejszyło się nasilenie trądziku. Ponadto uzyskano zmniejszenie stężenia testosteronu, dehydroepiandrosteronu oraz redukcję objawów hirsutyzmu [10]. Wiele innych badań również dowodzi skuteczności metforminy w leczeniu trądziku pospolitego, zarówno w monoterapii [11-14], jak i w terapii łączonej, np. z miejscowo aplikowanym nadtlenkiem benzoilu oraz $\mathrm{z}$ tetracykliną doustnie [15], stosowaną ogólnie limecykliną oraz miejscowo adapalenem w połączeniu z nadtlenkiem benzoilu [16], pioglitazonem oraz flutamidem stosowanymi doustnie [17]. Stwierdzono również inne efekty działania metforminy: korzystny wpływ na parametry biochemiczne (takie jak hiperinsulinemia, hipercholesterolemia i hiperglicerydemia), regulację cyklu miesiączkowego, zmniejszenie insulinooporności, redukcję stężenia testosteronu, androstendionu i wolnego testosteronu oraz normalizację wskaźnika masy ciała [11-13,17].

Ze względu na powyższe dane metformina jako lek zmniejszający stężenie IGF-1, hiperinsulinemię oraz insulinooporność może być przydatna w leczeniu trądziku pospolitego [5].

\section{HIDRADENITIS SUPPURATIVA}

Hidradenitis suppurativa (HS) jest przewlekłym stanem zapalnym zajmującym obszary skóry z gruczołami apokrynowymi, głównie doły pachowe, pachwiny oraz okolice anogenitalne. Zmiany zapalne są głęboko osadzone i bolesne, rozwijają się jako guzki lub ropnie ze skłonnością do rozmiękania i tworzenia przetok. Choruje ok. 1\% populacji, najczęściej po okresie dojrzewania.

Etiopatogeneza HS nie została dokładnie poznana, ale wykazano jej związek m.in. z cukrzycą, nadciśnieniem, hiperlipidemią, zespołem metabolicznym, insulinoopornością oraz otyłością [18].

Od wielu lat wiadomo, że metformina odgrywa ważną rolę w opóźnianiu lub zapobieganiu wystą- 
in the Sartorius score and the quality-of-life index depending on skin ailments was observed - in $72 \%$ and $64 \%$ of patients, respectively. Patients with HS were recruited prospectively, were metformin-naive and their HS was at least once unsuccessfully treated (including antibiotic and retinoid treatment) [21].

Jennings et al. conducted a study on a group of 53 patients with HS. All patients were receiving metformin. The average duration of treatment was 11.3 months and the average metformin dose was $1.5 \mathrm{~g} /$ day. In the subjective assessment of subjects, a clinical response was observed in $68 \%$, including $19 \%$ responses defined as "complete". No improvement was achieved in $25 \%$ of patients [20].

Metformin may exert anti-inflammatory effects by reducing the secretion of interleukin 6 (IL-6), IL-17, tumor necrosis factor- $\alpha$ (TNF- $\alpha)$, interferon- $\gamma$ (IFN- $\gamma)$ and increasing the activation of AMPK (adenosine monophosphate-activated protein kinase). Moreover, it improves the operation of the Th17-Treg axis, which is dysregulated in HS [20]. Hormones, and in particular androgens, have been reported to play an important role in the pathogenesis of HS. Metformin lowers insulin resistance, which indirectly leads to a reduction in serum androgen levels by up to $50 \%$ [19].

\section{MALIGNANT SKIN TUMORS}

Risk factors for skin cancers and melanoma include: skin phototype I-III determined according to the Fitzpatrick classification, exposure to UV radiation, obesity, family history of skin cancer, infection with oncogenic viruses, immunosuppressive treatment, status post organ transplantation [22, 23].

There are several studies describing a reduced risk of cancer development in patients with type 2 diabetes treated with metformin [24, 25], but no such an association was found in other studies [26-29]. Little has been published so far on the impact of metformin on the risk of skin malignancies.

In 2018, Tseng published a paper on the effect of metformin on the risk of skin cancer in patients with type 2 diabetes in Taiwan [22]. 16,237 patients treated with metformin were included in the study. The control group was the same number of patients, who had never been treated with metformin. The incidence of skin cancer in people using metformin was lower and amounted to 45.59 per 100,000 , compared to 83.90 per 100,000 in the group of people who had never used the drug. In addition, a reduction in the risk of developing skin cancers was observed with increasing cumulative dose and with duration of therapy. No such relationship was observed for melanoma (low number of melanoma cases). The limitation of the study was that it did not take into account other risk factors for developing skin cancers, such as UV radiation. pieniu cukrzycy i zespołu metabolicznego, ponadto zaobserwowano jej pozytywne działanie w leczeniu i kontrolowaniu objawów HS [19, 20].

W badanej grupie 25 osób z HS leczonych metforminą przez 24 tygodnie zaobserwowano znaczące obniżenie wyniku w skali Sartoriusa oraz wskaźnika jakości życia zależnej od dolegliwości skórnych - odpowiednio u 72\% i 64\% pacjentów. Pacjenci z HS byli rekrutowani prospektywnie, wcześniej nie otrzymywali metforminy i mieli za sobą co najmniej jedną nieskuteczną próbę leczenia HS (w tym antybiotykami i retinoidami) [21].

Jennings i wsp. przeprowadzili badanie $u 53$ pacjentów z HS, wszyscy chorzy otrzymywali metforminę. Średni czas leczenia wynosił 11,3 miesiąca, a średnia dawka 1,5 g/dobę. W subiektywnej ocenie badanych odpowiedź kliniczną zaobserwowano u 68\%, z czego u 19\% stwierdzono odpowiedź określoną jako „pełną". U 25\% pacjentów nie uzyskano poprawy [20].

Metformina może mieć działanie przeciwzapalne poprzez zmniejszenie sekrecji interleukiny 6 (IL-6), IL-17, czynnika martwicy nowotworów $\alpha$ (tumor necrosis factor- $\alpha-$ TNF- $\alpha$ ), interferonu $\gamma$ (IFN- $\gamma$ ) oraz wzrost aktywacji AMPK (adenosine monophosphate-activated protein kinase). Ponadto wpływa na poprawę działania osi Th17-Treg, która jest rozregulowana w HS [20]. Opisano ważną rolę hormonów, zwłaszcza androgenów, w patogenezie HS. Metformina zmniejsza insulinooporność, co pośrednio prowadzi do redukcji stężenia androgenów w surowicy nawet o 50\% [19].

\section{NOWOTWORY ZŁOŚLIWE SKÓRY}

Czynnikami ryzyka wystąpienia raków skóry oraz czerniaka są między innymi: fototyp skóry I-III wg klasyfikacji Fitzpatricka, ekspozycja na promieniowanie UV, otyłość, występowanie nowotworów skóry w rodzinie, zakażenie wirusami onkogennymi, leczenie immunosupresyjne, stan po transplantacji narządu [22, 23].

Istnieje kilka prac opisujących zmniejszone ryzyko zachorowania na nowotwory u pacjentów z cukrzycą typu 2 stosujących metforminę [24, 25], jednak pozostałe badania nie wykazały takiego związku [26-29]. Dotychczas opublikowano niewiele prac na temat wpływu metforminy na ryzyko występowania nowotworów złośliwych skóry.

W 2018 roku Tseng opublikował pracę na temat wpływu metforminy na ryzyko wystąpienia nowotworów skóry u pacjentów z cukrzycą typu 2 w Tajwanie [22]. Badanie obejmowało 16237 pacjentów stosujących ten lek, grupę kontrolną stanowiło tyle samo osób, które nigdy nie były leczone metforminą. Zachorowalność na raka skóry u osób stosujących lek była niższa i wyniosła 45,59 na 100 tys. w porównaniu z 83,90 na 100 tys. u osób, które nigdy nie stosowały metforminy. Ponadto zaobserwowano zmniejszenie ryzyka rozwoju raków skóry wraz ze wzrostem dawki kumulacyjnej oraz 
Ravishankar et al., published a paper on the effects of metformin on re-development of skin cancers [30]. This study did not show a reduced risk of developing a second cancer over 3 years in patients with type 2 diabetes treated with metformin, compared to patients not using metformin. Contrary to other studies, an increased risk of skin cancers was found in non-diabetic patients compared with both cohorts of diabetic patients. In addition, there was no significant effect of metformin on secondary variables including the time to onset of a second tumor, and the total number of skin cancers over 3 years.

The exact mechanisms by which metformin exerts its anti-neoplastic effects in skin cancer are not known. Studies in female mice receiving metformin in drinking water showed a significant reduction in the risk of skin cancer caused by carcinogens [31], and in vitro metformin exerted antitumor activity in melanoma cells [32]. Moreover, metformin reduces activation of the PI3K/Akt/mTOR signaling pathway and increases AMPK expression, which leads to cell cycle arrest, increased apoptosis and autophagy [33, 34]. By reducing the expression of target transcript proteins mediated by nuclear factor $\mathrm{k}$-light-chain-enhancer of activated $B$ cells (NF-kB), induced nitric oxide synthase (iNOS) and cyclooxygenase-2 (COX-2), and exerting an inhibitory effect on NF-kB/STAT3 pathways, metformin leads to a reduction in inflammation [34, 35]. Studies in mice showed that metformin administered topically or systemically, through its stimulating effect on AMPK, had a suppressive effect on proliferation of skin cancer cells and promoted repair of UVB-induced DNA damage [36]. These studies suggest that metformin may be an important chemopreventive agent, blocking development of skin cancers and melanoma in humans.

Due to the above-mentioned mechanisms of action of metformin, studies on the use of metformin in the treatment of melanoma, especially with BRAF and NRAS mutations, are carried on. To date, several studies have demonstrated the effect of metformin in reducing growth and progression of melanoma [33, 37-41].

\section{PSORIASIS}

Psoriasis affects $3-5 \%$ of the general population. It is a chronic, inflammatory disease manifested primarily with skin lesions, but it is currently assumed to be a systemic disease. Psoriatic arthritis may develop in the course of the disease [42], and a relationship between psoriasis and cardiovascular disease development factors, obesity, metabolic syndrome, and diabetes has also been demonstrated [43].

The case-control study carried out by Brauchli et al. in 2008 was designed to examine the effect of z czasem trwania terapii. Nie stwierdzono takiej zależności w przypadku czerniaka (mała liczba przypadków). Ograniczeniem badania było nieuwzględnienie innych czynników ryzyka zachorowania na nowotwory skóry, takich jak promieniowanie UV.

Ravishankar i wsp. opublikowali pracę na temat wpływu metforminy na powtórne rozwinięcie raków skóry [30]. W badaniu tym nie stwierdzono zmniejszonego ryzyka wystąpienia drugiego raka w czasie 3 lat u pacjentów z cukrzycą typu 2 leczonych metforminą w porównaniu z pacjentami niestosującymi tego leku. W przeciwieństwie do innych badań stwierdzono zwiększone ryzyko wystąpienia raków skóry u pacjentów bez cukrzycy w porównaniu z obiema kohortami pacjentów z cukrzycą. Ponadto nie wykazano znaczącego wpływu metforminy na zmienne wtórne, w tym czas do wystąpienia drugiego nowotworu i łączną liczbę raków skóry w czasie 3 lat.

Nie są znane dokładne mechanizmy, w których metformina działa przeciwnowotworowo w rakach skóry. $\mathrm{W}$ badaniach przeprowadzonych na samicach myszy otrzymujących metforminę $\mathrm{w}$ wodzie do picia stwierdzono znaczną redukcję ryzyka wystąpienia raka skóry wywołanego przez substancje rakotwórcze [31], a w badaniach in vitro metformina działała przeciwnowotworowo w komórkach czerniaka [32]. Ponadto lek ten zmniejsza aktywację szlaku sygnałowego PI3K/mTOR/Akt i zwiększa ekspresję AMPK, co prowadzi do zatrzymania cyklu komórkowego, zwiększenia apoptozy i autofagii [33, 34]. Poprzez zmniejszenie ekspresji docelowych białek transkrypcyjnych, w których pośredniczy czynnik jądrowy кВ (nuclear factor kappa-light-chain-enhancer of activated B cells NF-kB), indukowana syntaza tlenku azotu (induced nitric oxide synthase - iNOS) i cyklooksygenaza 2 (cyclooxygenase 2 - COX-2), oraz wywieranie hamującego wpływu na szlaki NF-kB/STAT3 metformina zmniejsza stan zapalny $[34,35]$. W badaniach na myszach dowiedziono, że podawana miejscowo lub ogólnie poprzez pobudzający wpływ na AMPK działa supresyjnie na proliferację komórek raka skóry oraz promuje naprawę uszkodzeń DNA indukowanych przez UVB [36]. Badania te sugerują, że metformina może być ważnym środkiem chemoprewencyjnym do blokowania rozwoju raków skóry i czerniaka u ludzi.

Z uwagi na powyższe mechanizmy działania metforminy trwają badania nad jej zastosowaniem w leczeniu czerniaka, szczególnie z mutacją BRAF i NRAS. W kilku dotychczasowych badaniach wykazano wpływ metforminy na zmniejszenie wzrostu i postępu czerniaka [33, 37-41].

\section{ŁUSZCZYCA}

Łuszczyca dotyczy 3-5\% populacji. Jest przewlekłym schorzeniem zapalnym, którego podstawową manifestację stanowią zmiany skórne, jednak aktualnie przyjmuje się, że to choroba ogólnoustrojowa. W jej 
oral antidiabetic drugs on the risk of psoriasis. The study included 36,702 people diagnosed with psoriasis for the first time in 1994-2005, and a control group. It was shown that the use of metformin for at least 3 years, or of drugs from the thiazolidinediones group for at least 1 year significantly reduced the risk of psoriasis. This effect was not demonstrated with other oral antidiabetic drugs. The study did not assess the minimum effective dose necessary to obtain such an effect, but only evaluated duration of the treatment with the above-mentioned drugs based on the analysis of medical records, which constitutes its disadvantage [44].

In 2003, the report of an 18-year-old woman who developed psoriasis on the skin of the trunk and limbs 1 week after starting metformin treatment was published. After the therapy was discontinued, these symptoms resolved within 5 weeks. Attempting to reuse the drug after 4 months resulted in re-appearance of lesions [45]. So far, this is the only case of metformin inducing psoriatic lesions. All other available case reports refer to patients in whom introduction of metformin resulted in improvement in condition of their skin in the course of psoriasis (2 patients described in 1974) [46].

The beneficial effect of metformin on condition of the skin was also assessed in the study of patients with psoriasis and concomitant metabolic syndrome (daily dose of metformin $1000 \mathrm{mg}$ for 12 weeks). In a randomized controlled trial on 38 people, a statistically significant reduction in the percentage of skin area occupied by erythema, scale and inflammatory infiltration was found in patients taking metformin. At the same time, no statistically significant change in the Psoriasis Area and Severity Index (PASI) and Physician Global Assessment (PGA) scores was demonstrated [47].

In diabetes, the effect of activation of AMPK in hepatocytes by metformin is used. It leads to a decrease in hepatic glucose production and an increase in insulin sensitivity [48]. The way metformin works on skin lesions in psoriasis has not yet been fully understood. In the case of macrophages and T cells, AMPK stimulation has an anti-inflammatory effect [49]. In vitro, metformin was shown to inhibit proliferation of human keratinocytes and secretion of pro-inflammatory cytokines by acting on the mTOR kinase [50]. Studies conducted on the HaCaT cell line demonstrated that it reduced the transcriptional activity of NF- $\mathrm{kB}$, which delayed activation of the inflammatory response [51]. In vivo, it was shown to inhibit keratinocyte proliferation by acting on mitogen-activated protein kinase (MAPK) [52]. In addition, the use of metformin decreased levels of inflammatory mediators (TNF-a, C-reactive protein) in blood serum [49]. przebiegu może dochodzić do rozwoju łuszczycowego zapalenia stawów [42]. Wykazano także związek łuszczycy z występowaniem czynników ryzyka rozwoju chorób sercowo-naczyniowych: otyłości, zespołu metabolicznego i cukrzycy [43].

Przeprowadzone przez Brauchli i wsp. w 2008 roku badanie kliniczno-kontrolne miało za zadanie zbadanie wpływu stosowania doustnych leków przeciwcukrzycowych na ryzyko wystąpienia łuszczycy. Badaniem objęto 36702 osoby z postawionym po raz pierwszy rozpoznaniem łuszczycy w latach 1994-2005 oraz grupe kontrolną. Wykazano, że stosowanie metforminy przez co najmniej 3 lata lub leków z grupy tiazolidynodionów przez co najmniej 1 rok istotnie zmniejsza ryzyko wystąpienia łuszczycy. Nie stwierdzono takiego efektu dla innych doustnych leków przeciwcukrzycowych. Wadą badania był brak oceny minimalnej skutecznej dawki potrzebnej do uzyskania takiego efektu - oceniano jedynie długość leczenia powyższymi lekami na podstawie analizy rejestrów medycznych [44].

W 2003 roku ukazało się doniesienie o przypadku 18-letniej kobiety, u której tydzień po rozpoczęciu leczenia metforminą wystąpiły rozsiane zmiany łuszczycowe na skórze tułowia i kończyn. Po zaprzestaniu farmakoterapii ustąpiły one w czasie 5 tygodni. Próba ponownego zastosowania leku po 4 miesiącach spowodowała nawrót zmian [45]. Jest to jedyny opisany dotychczas przypadek indukowania zmian łuszczycowych przez metforminę. Pozostałe dostępne opisy przypadków zastosowania leku w łuszczycy dotyczą pacjentów, u których włączenie metforminy do leczenia przyniosło poprawę stanu skóry w przebiegu łuszczycy (2 pacjentów opisanych w 1974 roku) [46].

Wpływ metforminy na stan skóry jako korzystny oceniono także w badaniu pacjentów z łuszczycą i współistniejącym zespołem metabolicznym (dzienna dawka metforminy $1000 \mathrm{mg}$ stosowana przez 12 tygodni). $\mathrm{W}$ badaniu $\mathrm{z}$ randomizacją z zastosowaniem placebo w grupie kontrolnej przeprowadzonym u 38 osób wykazano istotne statystycznie zmniejszenie procentowej powierzchni skóry zajmowanej przez rumień, łuskę oraz naciek zapalny u pacjentów przyjmujących metforminę. Jednocześnie nie stwierdzono jednak istotnej statycznie zmiany punktacji w skalach PASI (Psoriasis Area and Severity Index) oraz PGA (Physician Global Assessment) [47].

W cukrzycy wykorzystywany jest efekt aktywowania przez metforminę w hepatocytach AMPK, w wyniku którego dochodzi do zmniejszenia wątrobowej produkcji glukozy oraz zwiększenia insulinowrażliwości [48] Mechanizm działania metforminy na zmiany skórne w przebiegu łuszczycy nie został dotychczas jednoznacznie poznany. W przypadku makrofagów oraz limfocytów T pobudzenie AMPK ma efekt przeciwzapalny [49]. W warunkach in vitro wykazano, że metformina poprzez oddziaływanie na kinazę mTOR hamuje proliferację ludzkich keratynocytów oraz wydzielanie cytokin proza- 
Hirsutism is an excessive number of mature hairs in the areas of the body that are dependent on androgen. Excessive hair affects 5\% to $10 \%$ of women worldwide. It is associated with decreased quality of life and emotional stress. PCOS, which is associated with elevated androgen levels, is responsible for $75-80 \%$ of hirsutism. 5 to $20 \%$ of cases are due to idiopathic hirsutism, caused by increased levels of androgen. The remainder $(<5 \%)$ is due to rare but clinically significant conditions that include non-classical congenital adrenal hyperplasia, androgen-dependent tumors and Cushing's syndrome, as well as adverse drug reactions [53].

The meta-analysis by Barrionuevo et al., including 32 randomized controlled trials, showed that, insulin sensitizers, a combination of oral contraceptive pills (OCP) and insulin sensitizers, and a combination of antiandrogenic and antiandrogenic drugs insulin sensitizers were associated with a statistically significant reduction in the severity of hirsutism compared to placebo $(p<0.05)$ [54]. It was also found that the combination of antiandrogenic drugs and insulin sensitizers, and the combination of OCP and insulin sensitizers were more effective than insulin sensitizers. On a drug-specific basis, significant reductions in excessive hair growth compared to placebo were seen with the combination of OCP and metformin, the combination of flutamide and metformin and the combination of spironolactone and metformin. However, this effect is supported by evidence of very low quality.

In the meta-analysis Cosma et al. suggest that insulin sensitizers, including metformin, provide little benefit to women with hirsutism compared to placebo and provide no significant benefit compared to OCP and antiandrogens [55]. Analyzes in subgroups showed that insulin sensitizers appeared to be more effective than placebo when used in overweight or obese women. Metformin was more effective than OCP in one small study in which women were treated for over 6 months. Adding metformin to antiandrogens or OCP did not provide a significant benefit.

\section{CUTANEOUS ADVERSE EFFECTS OF METFORMIN}

Considering the increasing incidence of type II diabetes in Western countries (Europe, USA), the use of metformin as one of the basic drugs controlling hyperglycemia is increasing. Observations of patients taking metformin bring reports of adverse effects, some of them are skin complications related to the drug. The most common of these include erythema, itching and hives. Other complications, including se- palnych [50]. Badania prowadzone na linii komórkowej HaCaT pozwoliły ustalić, że zmniejsza ona aktywność transkrypcyjną NF-kB, co opóźnia uruchomienie odpowiedzi zapalnej [51]. In vivo wykazano hamujący wpływ na proliferację keratynocytów poprzez oddziaływanie na kinazy białkowe aktywowane mitogenami (mitogen-activated protein kinase - MAPK) [52]. Dodatkowo zastosowanie metforminy zmniejszało stężenie mediatorów zapalnych (TNF-a, białko C-reaktywne) w surowicy [49].

\section{HIRSUTYZM}

Hirsutyzm to nadmierna liczba dojrzałych włosów na obszarach ciała zależnych od działania androgenów. Dotyczy od 5\% do 10\% kobiet na świecie. Wiąże się z obniżeniem jakości życia i stresem emocjonalnym. Za 75-80\% przypadków hirsutyzmu odpowiada PCOS, który wiąże się z podwyższonym stężeniem androgenów. Od 5\% do $20 \%$ przypadków to idiopatyczny hirsutyzm, który jest spowodowany zwiększonym stężeniem androgenów. Pozostała część $(<5 \%)$ jest spowodowana rzadkimi, ale klinicznie istotnymi schorzeniami, które obejmują nieklasyczny wrodzony przerost nadnerczy, androgenozależne guzy oraz zespół Cushinga, a także działania niepożądane leków [53].

W metaanalizie Barrionuevo i wsp. obejmującej 32 badania kliniczne z randomizacją wykazano, że w porównaniu z placebo leki uwrażliwiające na działanie insuliny, skojarzenie doustnej antykoncepcji hormonalnej (oral contraceptive pills - OCP) i leków uwrażliwiających na insulinę oraz skojarzenie leków o działaniu antyandrogennym i leków uwrażliwiających na działanie insuliny były związane ze statystycznie istotnym zmniejszeniem nasilenia hirsutyzmu $(p<0,05)$ [54]. Stwierdzono także, że połączenie leków o działaniu antyandrogennym i środków uwrażliwiających na działanie insuliny oraz połączenie OCP i środków uwrażliwiających na działanie insuliny wykazywało większą skuteczność niż monoterapia środkami uwrażliwiającymi na działanie insuliny. Dla poszczególnych leków znaczące zmniejszenie nadmiernego owłosienia w porównaniu z placebo zanotowano w przypadku połączenia OCP i metforminy, flutamidu i metforminy oraz spironolaktonu i metforminy. Efekt ten jest jednak poparty dowodami o bardzo niskiej jakości.

Cosma i wsp. w metaanalizie sugerują, że leki uwrażliwiające na działanie insuliny, w tym metformina, zapewniają kobietom $\mathrm{z}$ nadmiernym owłosieniem niewielkie korzyści w porównaniu z placebo i nie przynoszą znaczącej korzyści w porównaniu z OCP i antyandrogenami [55]. Analizy podgrup wykazały, że leki uwrażliwiające na działanie insuliny wydają się bardziej skuteczne niż placebo, gdy są stosowane $\mathrm{u}$ kobiet $\mathrm{z}$ nadwagą lub otyłością. Metformina była bardziej skuteczna niż OCP w jednym badaniu z małą liczbą pacjentów, w którym kobiety były leczone przez ponad 6 miesięcy. 
vere and life-threatening, have been reported in the literature.

The first case of DRESS (drug reaction with eosinophilia and systemic symptoms) during the treatment with metformin was reported [56]. DRESS syndrome is a life-threatening drug reaction with eosinophilia and systemic symptoms. In a 40-yearold patient treated for psoriasis, hypertension, hyperlipidemia and newly diagnosed type II diabetes mellitus, DRESS was diagnosed, with presence of inflammatory papules surrounded by hyperpigmentation, associated with onycholysis, cervical lymphadenopathy and eosinophilia in peripheral blood counts.

Bullous pemphigoid (BP) may be another complication of metformin use. BP is a serious and severe autoimmune dermatosis that may be caused by chronic pharmacotherapy. Skandalis et al. described cases of BP when DPP-4 inhibitors (gliptins) were used in combination with metformin [57]. Kremer et al. noted that BP was significantly more common in people who used metformin [58].

Erythroderma with pruritus was also reported in case of concomitant use of metformin and sitagliptin [59]. The reported patient developed urticaria while taking metformin and developed erythroderma several years later after additional introduction of sitagliptin.

Baron described a case of leukocytoclastic vasculitis and pneumonia in a 59-year-old woman who had been taking metformin for a month [60]. The patient was admitted to the dermatology ward due to polymorphic changes on the skin on the whole body, arthritis, and painful ankle swelling. Chest $X$-ray revealed bilateral basal inflammatory infiltrates. In the treatment, prednisone $0.5 \mathrm{mg} / \mathrm{kg} \mathrm{bw} /$ day was used, and metformin was discontinued. The patient's condition improved immediately. Metformin was restarted after 2 weeks of treatment. The same symptoms appeared within 2 days of re-introduction of metformin.

A case of metformin-induced allergic vasculitis was also reported [61]. Erythematous changes in the groin, thighs and genitals area appeared after introduction of metformin. The patient was not taking any other medications. A similar allergic reaction was reported by Mumoli et al. Metformin and levothyroxine were started in a 29-year-old female patient with insulin resistance and hypothyroidism [62]. Two days after introduction of the drug, the patient developed a rash on the center of her face, burning sensation and severe itching. After a month, lesions intensified, with papular rash and telangiectasias spread over the entire face. After discontinuation of metformin, symptoms resolved spontaneously within 1 month.
Dodanie metforminy do antyandrogenów lub OCP nie zapewniło znaczącej korzyści [55].

\section{SKÓRNE DZIAŁANIA NIEPOŻĄDANE METFORMINY}

Z powodu coraz częstszego występowania cukrzycy typu 2 w społeczeństwach krajów zachodnich (Europa, USA) rozpowszechnia się stosowanie metforminy jako jednego z podstawowych leków kontrolujących hiperglikemię. Obserwacje pacjentów przyjmujących ten lek wskazują na możliwość wystąpienia działań niepożądanych, z których część stanowią powikłania skórne. Do najczęstszych z nich należą: rumień, świąd i pokrzywka. W piśmiennictwie opisano także inne powikłania po zastosowaniu tego leku, w tym ciężkie i zagrażające życiu.

Opisano pierwszy przypadek wystąpienia zespołu DRESS (drug reaction with eosinophilia and systemic symptoms) podczas stosowania metforminy [56]. Zespół DRESS to zagrażająca życiu reakcja polekowa z eozynofilią i objawami ogólnymi. U 40-letniego pacjenta leczącego się na łuszczycę, nadciśnienie tętnicze, hiperlipidemię oraz nowo rozpoznaną cukrzycę typu 2 postawiono diagnozę zespołu DRESS ze względu na wystąpienie grudek zapalnych z hiperpigmentacją wokół zmian, połączonych z onycholizą, limfadenopatią węzłów szyjnych i eozynofilią w morfologii krwi obwodowej.

Pemfigoid pęcherzowy może być kolejnym powikłaniem po zastosowaniu metforminy (bullous pemphigoid - BP) - dermatoza o podłożu autoimmunologicznym, której wystąpienie może być związane z działaniem leków. Skandalis i wsp. opisali przypadki wystąpienia BP podczas stosowania inhibitorów DPP-4 (gliptyn) w połączeniu z metforminą [57]. Kremer i wsp. zaznaczają, że BP występuje istotnie częściej u osób stosujących metforminę [58].

Opisano także występowanie erytrodermii z towarzyszącym świądem przy jednoczesnym stosowaniu metforminy i sitagliptyny [59]. U opisywanego pacjenta podczas stosowania metforminy wystąpiła pokrzywka, a kilka lat później po dodaniu sitagliptyny erytrodermia.

Baron opisał przypadek leukocytoklastycznego zapalenia naczyń i zapalenia płuc u 59-letniej kobiety, która od miesiąca przyjmowała metforminę [60]. Pacjentkę przyjęto na oddział dermatologii z powodu polimorficznych zmian na całej skórze, zapalenia stawów, bolesnego obrzęku w okolicy stawów skokowych. W badaniu rentgenograficznym (RTG) klatki piersiowej stwierdzono obustronne przypodstawne nacieki zapalne. $W$ leczeniu zastosowano prednizon w dawce 0,5 mg/kg m.c./dobę oraz odstawiono metforminę. Nastąpiła bardzo szybka poprawa stanu pacjentki. Po 2 tygodniach leczenia ponownie włączono metforminę. Po 2 dniach stosowania leku wystąpiły identyczne obja- 


\section{CONCLUSIONS}

Metformin has been long established in the treatment of diabetes. Numerous reports indicate that apart from well-known indications for the use of metformin, it may also be useful in the treatment of skin diseases, in particular those related to hyperinsulinemia and hyperandrogenism.

\section{CONFLICT OF INTEREST}

The authors declare no conflict of interest. wy jak wcześniej, po 2 dniach leczenia nastąpił nawrót opisanych uprzednio objawów.

Opisano również przypadek alergicznego zapalenia naczyń indukowanego metforminą [61]. Zmiany w postaci rumienia w okolicy pachwin, ud i narządów płciowych pojawiły się po rozpoczęciu stosowania metforminy. Pacjentka nie przyjmowała innych leków. Inne zmiany skórne potencjalnie związane $\mathrm{z}$ metformina opisali Mumoli i wsp. u 29-letniej pacjentki z insulinoopornością i niedoczynnością tarczycy po rozpoczęciu leczenia metforminą i lewotyroksyną [62]. Dwa dni po rozpoczęciu leczenia metforminą $\mathrm{w}$ centralnej części twarzy wystąpiły zmiany skórne, pieczenie i nasilony świąd. Po miesiącu zmiany się nasiliły, grudki i teleangiektazje zajmowały całą skórę twarzy. Po odstawieniu metforminy objawy ustąpiły samoistnie w czasie miesiąca.

\section{PODSUMOWANIE}

Metformina od wielu lat ma ugruntowaną pozycję w leczeniu cukrzycy. Liczne doniesienia pokazują, że oprócz dobrze poznanych już wskazań może być również przydatna w leczeniu chorób skóry, w szczególności związanych z hiperinsulinemią i hiperandrogenizmem.

\section{KONFLIKT INTERESÓW}

Autorzy nie zgłaszają konfliktu interesów.

References

\section{Piśmiennictwo}

1. Bailey C.J.: Metformin: historical overview. Diabetologia 2017, 60, 1566-1576.

2. Turner R.C., Holman R.R., Stratton I.M., Cull C.A., Matthews D.R., Manley S.E., et al.: Effect of intensive blood-glucose control with metformin on complications in overweight patients with type 2 diabetes (UKPDS 34). Lancet 1998, 352, 854-865.

3. Rena G., Hardie D.G., Pearson E.R.: The mechanisms of action of metformin. Diabetologia 2017, 60, 1577-1585.

4. Bergler-Czop B.: The aetiopathogenesis of acne vulgaris - what's new? Int J Cosmet Sci 2014, 36, 87-94.

5. Stanescu A.M.A., Grajdeanu I.V., Miricescu D., Serban B., Lazarescu H., Brezan F., et al.: Does metformin play a role in the treatment of acne? Arch Balk Med Union 2019, 54, 745-748.

6. Behrangi E., Rasi A., Navid P., Dalvand B., Azizian Z.: Serum level of insulin-like growth factor 1 in patients with acne vulgaris versus healthy subjects. J Skin Stem Cell 2018, 5, e79784.

7. Emiroğlu N., Cengiz F.P., Kemeriz F.: Insulin resistance in severe acne vulgaris. Adv Dermatol Allergol 2015, 32, 281-285.

8. Vora S., Ovhal A., Jerajani H., Nair N., Chakrabortty A.: Correlation of facial sebum to serum insulin-like growth factor-1 in patients with acne. Br J Dermatol 2008, 159, 990-991.

9. Smith R., Mann N., Mäkeläinen H., Roper J., Braue A., Varigos G.: A pilot study to determine the short-term effects of a low glycemic load diet on hormonal markers of acne: a nonrandomized, parallel, controlled feeding trial. Mol Nutr Food Res 2008, 52, 718-726.

10. Sharma M., Nazareth I., Petersen I.: Trends in incidence, prevalence and prescribing in type 2 diabetes mellitus between 2000 and 2013 in primary care: a retrospective cohort study. BMJ Open 2016, 6, e010210.

11. Tan S., Hahn S., Benson S., Dietz T., Lahner H., Moeller L.C., et al.: Metformin improves polycystic ovary syndrome symptoms irrespective of pre-treatment insulin resistance. Eur J Endocrinol 2007, 157, 669-676.

12. Fabbrocini G., Izzo R., Faggiano A., Del Prete M., Donnarumma M., Marasca C., et al.: Low glycaemic diet and metformin therapy: a new approach in male subjects with acne resistant to common treatments. Clin Exp Dermatol 2016, 41, 38-42.

13. De Leo V., Musacchio M.C., Morgante G., Piomboni P., Petraglia F.: Metformin treatment is effective in obese teenage girls with PCOS. Hum Reprod 2006, 21, 2252-2256.

14. Israni D.A., Mehta T.Y., Shah S.R., Goyal R.K.: Effect of metformin therapy in female visiting dermatologist for acne vulgaris having endocrine and sonographic characteristics of polycystic ovary syndrome (PCOS). Asian J Pharm Clin Res 2013, 6, 76-82. 
15. Robinson S., Kwan Z., Tang M.M.: Metformin as an adjunct therapy for the treatment of moderate to severe acne vulgaris: a randomized open-labeled study. Dermatol Ther 2019, 32, e12953.

16. Lee J.K., Smith A.D.: Metformin as an adjunct therapy for the treatment of moderate to severe acne vulgaris. Dermatol Online J 2017, 23, 5-6

17. Ibáñez L., Diaz M., Sebastiani G., Sánchez-Infantes D., Salvador C., Lopez-Bermejo A., et al.: Treatment of androgen excess in adolescent girls: ethinylestradiol-cyproterone acetate versus low-dose pioglitazone-flutamide-metformin. J Clin Endocrinol Metab 2011, 96, 3361-3366.

18. Shalom G., Freud T., Harman-Boehm I., Polishchuk I., Cohen A.D.: Hidradenitis suppurativa and metabolic syndrome: a comparative cross-sectional study of 3207 patients. Br J Dermatol 2015, 173, 464-470.

19. Nikolakis G., Kyrgidis A., Zouboulis C.C.: Is there a role for antiandrogen therapy for hidradenitis suppurativa? A systematic review of published data. Am J Clin Dermatol 2019, 20, 503-513.

20. Jennings L., Hambly R., Hughes R., Moriarty B., Kirby B.: Metformin use in hidradenitis suppurativa. J Dermatolog Treat 2020, 31, 261-263.

21. Verdolini R., Clayton N., Smith A., Alwash N., Mannello B.: Metformin for the treatment of hidradenitis suppurativa: a little help along the way. J Eur Acad Dermatol Venereol 2013, 27, 1101-1108.

22. Tseng C.H.: Metformin is associated with decreased skin cancer risk in Taiwanese patients with type 2 diabetes. J Am Acad Dermatol 2018, 78, 694-700

23. Imko-Walczuk B., Roskosz-Stożkowska M., Szymańska K., Kadylak D., Dębska-Ślizień A.: Skin cancer in children after organ transplantation. Adv Dermatol Allergol 2019, 36, 649-654.

24. Currie C.J., Poole C.D., Gale E.A.M.: The influence of glucose-lowering therapies on cancer risk in type 2 diabetes. Diabetologia 2009, 52, 1766-1777.

25. Libby G., Donnelly L.A., Donnan P.T., Alessi D.R., Morris A.D., Evans J.M.M.: New users of metformin are at low risk of incident cancer: a cohort study among people with type 2 diabetes. Diabetes Care 2009, 32, 1620-1625.

26. Van Staa T.P., Patel D., Gallagher A.M., De Bruin M.L.: Glucose-lowering agents and the patterns of risk for cancer: a study with the General Practice Research Database and secondary care data. Diabetologia 2012, 55, 654-665.

27. Tsilidis K.K., Capothanassi D., Allen N.E., Rizos E.C., Lopez D.S., Van Veldhoven K., et al.: Metformin does not affect cancer risk: a cohort study in the U.K. clinical practice research datalink analyzed like an intention-to-treat trial. Diabetes Care 2014, 37, 2522-2532.

28. Ko E.M., Stürmer T., Hong J.L., Castillo W.C., Bae-Jump V., Funk M.J.: Metformin and the risk of endometrial cancer: a population-based cohort study. Gynecol Oncol 2015, 136, 341-347.

29. Farmer R.E., Ford D., Mathur R., Chaturvedi N., Kaplan R., Smeeth L., et al.: Metformin use and risk of cancer in patients with type 2 diabetes: a cohort study of primary care records using inverse probability weighting of marginal structural models. Int J Epidemiol 2019, 48, 527-537.

30. Ravishankar A., Zhang T., Lindgren B.R., Farah R.S., Dong Z., Goldfarb N.I.: The effect of metformin on the risk of recurrent nonmelanoma skin cancers. Int J Dermatol 2020, 59, e303-e305.

31. Checkley L.A., Rho O., Angel J.M., Cho J., Blando J., Beltran L., et al.: Metformin inhibits skin tumor promotion in overweight and obese mice. Cancer Prev Res 2014, 7, 54-64.

32. Snima K., Pillai P., Cherian A., Nair S., Lakshmanan V.K.: Anti-diabetic drug metformin: challenges and perspectives for cancer therapy. Curr Cancer Drug Targets 2014, 14, 727-736.

33. Ryabaya O., Prokofieva A., Akasov R., Khochenkov D., Emelyanova M., Burov S., et al.: Metformin increases antitumor activity of MEK inhibitor binimetinib in 2D and 3D models of human metastatic melanoma cells. Biomed Pharmacother 2019, 109, 2548-2560.

34. Chaudhary S.C., Kurundkar D., Elmets C.A., Kopelovich L., Athar M.: Metformin, an antidiabetic agent reduces growth of cutaneous squamous cell carcinoma by targeting mTOR signaling pathway. Photochem Photobiol 2012, 88, 1149-1156.

35. Chu N.J., Armstrong T.D., Jaffee E.M.: Nonviral oncogenic antigens and the inflammatory signals driving early cancer development as targets for cancer immunoprevention. Clin Cancer Res 2015, 21, 1549-1557.

36. Wu C.L., Qiang L., Han W., Ming M., Viollet B., He Y.Y.: Role of AMPK in UVB-induced DNA damage repair and growth control. Oncogene 2013, 32, 2682-2689.

37. Cerezo M., Tomic T., Ballotti R., Rocchi S.: Is it time to test biguanide metformin in the treatment of melanoma? Pigment Cell Melanoma Res 2015, 28, 8-20.

38. Tomic T., Botton T., Cerezo M., Robert G., Luciano F., Puissant A., et al.: Metformin inhibits melanoma development through autophagy and apoptosis mechanisms. Cell Death Dis 2011, 2, e199.

39. Vujic I., Sanlorenzo M., Posch C., Esteve-Puig R., Yen A.J., Kwong A., et al.: Metformin and trametinib have synergistic effects on cell viability and tumor growth in NRAS mutant cancer. Oncotarget 2015, 6, 969-978.

40. Jaune E., Rocchi S.: Metformin: focus on melanoma. Front Endocrinol 2018, 9, 472.

41. Yu X., Zhou W., Wang H., Lu S., Jin Y., Fu J.: Transdermal metformin hydrochloride-loaded cubic phases: in silico formulation optimization, preparation, properties, and application for local treatment of melanoma. Drug Deliv 2019, 26, 376-383.

42. Reich A., Adamski Z., Chodorowska G., Kaszuba A., Krasowska D., Lesiak A., et al.: Psoriasis. Diagnostic and therapeutic recommendations of the Polish Dermatological Society. Part 1. Dermatol Rev 2020, 107, 92-109.

43. El-Gharabawy R.M., Ahmed A.S., Al-Najjar A.H.: Mechanisms of action and effect of immune-modulating agents in the treatment of psoriasis. Biomed Pharmacother 2017, 85, 141-147.

44. Brauchli Y.B., Jick S.S., Curtin F., Meier C.R.: Association between use of thiazolidinediones or other oral antidiabetics and psoriasis: a population based case-control study. J Am Acad Dermatol 2008, 58, 421-429.

45. Koca R., Altinyazar H.C., Yenidünya S., Tekin N.S.: Psoriasiform drug eruption associated with metformin hydrochloride: a case report. Dermatol Online J 2003, 9, 11.

46. Babad F.: Psoriasis and phenformin hydrochloride: a report on 2 cases. J Med Soc N J 1974, 71, 412. 
47. Singh S., Bhansali A.: Randomized placebo control study of metformin in psoriasis patients with metabolic syndrome (systemic treatment cohort). Indian J Endocrinol Metab 2017, 21, 581-587.

48. Ip W., Kirchhof M.G.: Glycemic control in the treatment of psoriasis. Dermatology 2017, 233, $23-29$.

49. Krysiak R., Okopien B.: Lymphocyte-suppressing and systemic anti-inflammatory effects of high-dose metformin in simvastatin-treated patients with impaired fasting glucose. Atherosclerosis 2012, 225, 403-407.

50. Li W., Ma W., Zhong H., Liu W., Sun Q.: Metformin inhibits proliferation of human keratinocytes through a mechanism associated with activation of the MAPK signaling pathway. Exp Ther Med 2014, 7, 389-392.

51. Liu Y., Yang F., Ma W., Sun Q.: Metformin inhibits proliferation and proinflammatory cytokines of human keratinocytes in vitro via mTOR-signaling pathway. Pharm Biol 2016, 54, 1173-1178.

52. Ba W., Xu Y., Yin G., Yang J., Wang J, Chi R., et al.: Metformin inhibits pro-inflammatory responses via targeting nuclear factor-kappaB in HaCaT cells. Cell Biochem Funct 2019, 37, 4-10.

53. Mimoto M.S., Oyler J.L., Davis A.M.: Evaluation and treatment of hirsutism in premenopausal women. J Am Med Assoc 2018, 319, 1613-1614.

54. Barrionuevo P., Nabhan M., Altayar O., Wang Z., Erwin P.J., Asi N., et al.: Treatment options for hirsutism: a systematic review and network meta-analysis. J Clin Endocrinol Metab 2018, 103, 1258-1264.

55. Cosma M., Swiglo B.A., Flynn D.N., Kurtz D.M., LaBella M.L., Mullan R.J., et al.: Insulin sensitizers for the treatment of hirsutism: a systematic review and metaanalyses of randomized controlled trials. J Clin Endocrinol Metab 2008, 93, 1135-1142.

56. Voore P., Odigwe C., Mirrakhimov A.E., Rifai D., Iroegbu N.: DRESS syndrome following metformin administration: a case report and review of the literature. Am J Therapeutics 2016, 23, 1970-1973.

57. Skandalis K., Spirova M., Gaitanis G., Tsartsarakis A., Bassukas I.D.: Drug-induced bullous pemphigoid in diabetes mellitus patients receiving dipeptidyl peptidase-IV inhibitors plus metformin. J Eur Acad Dermatol Venereol 2012, 26, $249-253$.

58. Kremer N., Zeeli T., Sprecher E., Geller S.: Failure of initial disease control in bullous pemphigoid: a retrospective study of hospitalized patients in a single tertiary center. Int J Dermatol 2017, 56, 1010-1016.

59. Nakatani K., Kurose T., Hyo T., Watanabe K., Yabe D., Kawamoto T., et al.: Drug-induced generalized skin eruption in a diabetes mellitus patient receiving a dipeptidyl peptidase-4 inhibitor plus metformin. Diabetes Ther 2012, 3, 14.

60. Baron J.: Leucocytoclastic vasculitis and pneumonitis induced by metformin. Br Med J 1986, $293,23$.

61. Wiwanitkit V.: Metformin allergy. Indian J Pharmacol 2011, 43, 216-217.

62. Mumoli L., Gambardella A., Labate A., Succurro E., De Sarro G., Artur D., et al.: Rosacea-like facial rash related to metformin administration in a young woman. BMC Pharmacol Toxicol 2014, 15, 3.

Received: 21.08 .2020

Accepted: 14.10 .2020

Otrzymano: $21.08 .2020 \mathrm{r}$.

Zaakceptowano: $14.10 .2020 \mathrm{r}$. 